Lomza State University of Applied Sciences,

Poland

\title{
THE CONCEPT OF PUBLIC SAFETY AND ORDER IN THE SOCIAL AND THE HUMANITIES SCIENCES
}

\begin{abstract}
Public safety and public order are a main welfare desirable by man and the entire community, in every epoch and every longitude, parallely has become the constant object of doctrinal inquiries. The specificity of each area of science and many other fields of science, their qualities and the desirable elements made the definition of these values, depending on the discipline of science, which adopted a different shape. Security and public order in the legal sciences are mostly expressed in the matter of substantive administrative law and subsequently also in constitutional law and substantive criminal law. The importance of this issue is evidenced by the creation of a new discipline - the Security Science, dedicated to this subject, by the resolution of the Central Commission for Degrees and Titles of $28^{\text {th }}$ January 2011, which discusses the title issue in a multi-threaded and multifaceted manner. The specificity of security, its subjective perception and the state of reality, forces the concept to be analyzed also from the perspective of psychology, sociology and philosophy. On the other hand, for a deeper investigation of this phenomenon, the origin of its development and the formulation of future trends, it is important to examine this phenomenon by the historical instruments.
\end{abstract}

KEYWORDs: public safety, public order, law, security science, history, philosophy, sociology, psychology.

\section{INTRODUCTION}

The term of security is used in various fields of knowledge describing both the reality in which man lives and functions. Many other terms, used in the 
Polish language, are ambiguous, and depending on the area of analysis or field of knowledge is differently defined. In addition, it also occurs in conjunction with other concepts and thus achieves further contextual meaning. As a result, there is great diversity and often lack of unambiguity in terms of safety (Pomykała, 2010, p. 107). In situation where the same concepts are applied in many areas of knowledge or are interdisciplinary, there is a danger of misunderstanding the significance of a specific scientific specialty or area of knowledge (Klamut, 2012, p. 41). Due to the thematic scope of work, it is crucial to establish a definition of safety in the legal sciences and in the science of safety. However, for the vide knowledge of the subject, it is also necessary to analyze the definition of safety in such disciplines as history, philosophy, sociology and psychology.

\section{Public law}

Although the notion of public security and public order are not identical, in the subject literature they are almost inseparable. As J. Dobkowski observes, in principle, all authors who deal with the meaning of these concepts consider them unclear, imprecise, incomplete, ambiguous, terminologically inaccurate, and as a result difficult to define and delimit. In Polish legislation, as well as in the context of community law, these concepts are defined and used as unspecified, blurred, ambiguous, legally undefined and evaluative (Dobkowski, 2008, pp.159-160).

The concept of public security occurs in normative acts, both statutory and lower order. The scope of application of this concept by the legislature, in various legal regulations, is steadily increasing in the world due to the growing legal as well as social and political role of public security. It should be emphasized, however, that the notion of public safety, which is incidentally the most important task of the state and its most important function, has not been precisely defined in the law. In legal literacy, this issue is often presented in a fragmented way, referring only to particular areas of law. The legislator uses this term frequently in various regulations, however its scope is very often ambiguous. This creates a lot of trouble in the interpretation of legal norms (Filaber, 2009, p. 244). Security and its protection are the subject of legal regulation in all branches of law. They occur in different contexts and 
in connection with many other phenomena. Under constitutional law, the security appears as a separate object of protection, in food law as a soughtafter feature of the objects, in road traffic law it allows to describe the correct behavior of people in traffic situations, but in many other cases it is a prerequisite for the application of detailed rules and procedures. It can be seen that this concept is most often found in the branches of law that are included in public law: constitutional, administrative and criminal. Despite numerous rules, none of the regulations explains what safety is (Pomykała, 2012, p. 87). Nevertheless, the term in question finds its development also in the on the judgments of the Constitutional Tribunal, the Supreme Court and the Supreme Administrative Court.

The legal basis of Poland's internal security system is the Constitution of the Republic of Poland (Journal of Laws No. 78, item 483, as amended). In the general law, the concept of safety occurs many times, including public security, state security, citizens' security, internal security, external security and ecological security. This multiplicity is due to the fact that security is the most important element of a state functioning (Filaber, 2009, pp. 246-247). For reasons of security and public order, the constitution allows for certain restrictions on fundamental rights and freedoms.

In addition, it should be pointed out that the limitation of rights and freedoms is permissible both when expressly permitted by the provisions of the Constitution and when there is a need for mutual harmonization of individual rights or freedoms with other norms, principles or values expressed in the Constitution. Thus, state's interference in the sphere of freedom and human rights can only take place in the context of its implementation of values protected by the Constitution (Wojtyczek, 1999, p. 179). Undoubtedly, such constitutional value, justifying the establishment of restrictions on the exercise of constitutional freedoms and rights, is public safety, in addition to public policy, environmental protection, public health and morality, listed expressis verbis in Art. $31 \mathrm{sec} .3$ of the Constitution of the Republic of Poland (Filaber, 2009, pp. 247-248).

In administrative law, the definition of security and public order was included in the laws and regulations governing the issue. On the other hand, the definitions of security in it apply only to the area that governs the act. 
An example is the Act of March 8, 1990 on municipal self-government (Journal of Laws of 2016, item 446) meeting the collective needs of the community belongs to the municipality's own tasks, in particular those concerning public order and security of citizens and fire and flood protection, including the equipment and maintenance of the municipal flood protection warehouse.

In the doctrine of criminal law, it can be said that it is the security that is the independent object of protection. These regulations fulfill the basic purpose of criminal law, which is to set boundaries and provide tools to evaluate human behavior in terms of their social harm (Pomykała, 2012, p. 95). A. Marek emphasizes that universal security is a good and that it is materialized in the provisions of the Penal Code (Journal of Laws of 2016, item 1137), in which either the threat to the life or health of many persons or property is large, or there is no indication of it, although it is undoubtedly a universal threat, i.e. about a larger, nearer unspecified number of people and large size property (Marek, 2007, p. 340). Unlike G. Bogdan who argues that these regulations serve the protection of differentiated legal goods, which depending on the actual situation, will be the life or health of many persons or property in great proportions. Universal security, which cannot be granted autonomous legal status, is merely a socially desirable state characterized by the absence of threats of significant value (Bogdan, 2016, LEX). It seems that, in the context of criminal liability for the commission of the offenses set forth in chapters XX and XXI of the Penal Code, there is no way to clearly separate security from the other values like life, health or property. Assuming that security is a state of confidence and peace, and respect for other values, it can be argued that security is a value that arises and depends on others. For this reason, the protection of the indicated provisions of the Penal Code is not only about life, health or property but above all about the state of certainty, peace and respect for those goods in the form of specific security (Pomykała, 2012, p. 95).

\section{SCIENCE OF SAFETY}

Safety science is a relatively young discipline. It was created by the resolution of the Central Commission for Degrees and Titles of $28^{\text {th }}$ January 2011 amending the resolution on determining the fields of science and art as well as scientific and artistic disciplines (M.P. 2011, No. 14, item 149). Safety 
sciences have been placed in the field of social sciences due to the expense of military sciences, and in my opinion was the right solution, as A. Misiuk writes, military sciences do not have a solid merchandise, and presented research is conducted only at several military academies. The right choice of placing the Security Science in the Field of Social Science is stated by A. Misiuk for the following issues: firstly, the perception of security issues in military terms is characteristic for the authoritative political systems, and secondly, contemporary issues of internal security are primarily civil and finally interdisciplinary. Scientific discipline requires perception (research) through the prism of political, social, religious and economic determinants (Misiuk, 2011, p. 11).

Many attempts to define the terms public safety and public order were often undertaken in Polish scientific literature. In principle, all authors dealing with this problem consider our concept as indeterminate, and therefore difficult to define (Ura, 1997, p.97).

In the interwar period in Poland, this problem was dealt by W. Czapiński and W. Kawka (Zaborowski, 1977, p. 7). The first representative of the doctrines was very closely bound by these concepts with their content, but he did not elaborate it exactly. Consequently, his arguments proved to be inaccurate and did not explain them in principle (Bolesta, 1972, p. 102). The more precise definition of these concepts can be found in W. Kawka's reflections, which state that public order, peace and security are elements of a certain state, enabling a society of undisturbed coexistence and development to be organized (Zaborowski, 1977, p.7). The representative of those days was also S. Glaser, who defined public order as a state of security existing in society, the state of undisturbed public order or from the subjective point of view, the state of public awareness of the existence of this state (Glaser, 1933, p. 355).

The Bolest's public policy definition is described by public-law and social relations, which arises in public places (in the open and in public places that all people can use). It is a well-defined definition of security and public order. It is related with social relationships that arise or develop in non-public places, in particular providing protection for the life, health and property of citizens and social property (Bolesta, 1972, p. 108). What is more it turns on 
public security, the system of social relations and devices regulated by law and moral norms, rules of social cohesion, providing protection for society and individuals as well as to their property against the dangers of violent human activity and the forces of nature (Bolesta, 1972, p. 121).

According to A. Misiuk, the public security is a state of no danger to the functioning of a state organization and its interests, preventing normal, free development. On the other hand, the public order of A. Misiuk defines as actually existing social relations, regulated by a set of legal norms and other socially accepted norms, guaranteeing uninterrupted and conflict-free functioning of individuals in society (Misiuk, 2011, pp. 17-18).

S. Pieprzny states that public security is a positive state within a country largely determined by external security, which enables the optimal functioning of people and their communities, all other public and private entities present in the state. While public order is a positive state of affairs accepted by the majority of people, also positively influencing the individual (Pieprzny, 2012, p. 15).

On the other hand, E.Ura states that the public safety defines a state in which the general public of the unmarried individuals living in the state and society is in no danger and no matter what its source (Ura, 1974, p.76).

For J. Zaborowski, the public safety is a state of affairs within the state which allows for the exposure on defects (caused by the behavior of people as well as by the forces of nature, technology, etc.). The normal functioning of a state organization and the pursuit of its interests, the preservation of life, health and property, living individuals in this organization... and the uses by those individuals of the rights and freedoms guaranteed (Zaborowski, 1977, p.129). On the other hand E. Pływaczewski states that public safety is a higher order of public order (Pływaczewski, 1985, p. 16).

S. Pikulski's concept of public safety defines a certain state of affairs, ensuring uninterrupted functioning of public facilities in the state and the security of citizens' lives, including protection of their lives and health and property. Due to the fact that public safety can be disturbed in the size of the whole system, in some situations it may be in terms of state danger. In other situations, it may occur in terms of common danger. Public safety can be disturbed by man intentionally or unintentionally, and such acts may be 
treated as offenses, but may also be disturbed independently of man will, that is by the forces of nature: floods, fires, collapses of buildings, environmental poisoning, etc. (Pikulski, 2000., P. 101).

Although, there are differences in the definition of public safety and public policy, there are situations where both concepts can be treated equally. The lack of proper road maintenance, breaks the public order, but at the same time it threatens public safety as it can lead to the road accidents. The croaking of snow, not removed from the roadside, not only dirty the roads, but also threaten the safety of communication, causing car accidents and pedestrians. Likewise, it can be considered the lack of lighting in parks or in the streets. It can be assumed that public order is an element of public security, the external manifestation of which is the observance of legal, moral and religious norms by natural persons and other entities, which results in the harmonization of lives of individuals and human communities (Ura, Pieprzny, Pado, 2007, pp. 165-166).

\section{History}

The issue of security and public order, as for any social phenomenon, we should look at in a historical cross-section. This allows us better understanding of this complex problem. The state, as a legal institution, has undergone various transformations over the centuries. Every socio-political formation brought with it new solutions. In each of them there were, in one form or another, a section of security and public order, most often called the police (Antonowicz, Łukasik, 2011, p. 5).

Police concept goes back to ancient times. The term police comes from the Greek word "polis", describe the city and the word politeia, meaning the prosperity and security of its inhabitants. Politeia in cities and countries has been the concern of all citizens, at the same time being a common and democratic obligation. The Romans embraced and latinized this term and created the notion of politism by transferring the related powers to the emperor under the supreme authority of the imperial. The police force was thought to be at the heart of state power. In the Middle Ages, alongside the expression of politia, appeared policite and police, which were called state activities aimed to ensure security, order and prosperity (Pokruszyński, Straszewski, Terlikowski, 1996, p. 7). 
The 14th and 15th century was a period of consolidation of state power, change views on the tasks and goals of the state. The word politia was used more frequent at that time, containing content about the strengthening of state power and the increase of state tasks. Coming from the police law word "ius politia" becomes the general norm on which the authority's activities are based, aiming at the attainment of prosperity and the general "happiness" of the subjects. This resulted in a new type of police state. The period of its greatest significance was in the seventeenth and eighteenth centuries. The essential elements of the state as an organization became the authority strong power and the absolute obedience of the subjects. Based on the ius politiae, the ruling power did what they wanted - the every statement of their wills had the power of law. At the beginning of the 17th century, the foreign, military and treasury matters were distinguished from the general scope of police operations, and in the 18th century the judiciary. After the separation of these branches, the concept of police was understood today as internal administration and legislation. However, it should be noted, that in the eighteenth century, both the legislative and the legislative powers were centered on the ruling hand. The police remained a state activity aimed at maintaining public order in the interest of the authorities (Pokruszyński, Straszewski, Terlikowski, 1996, p. 8).

Security, peace and public order, due to their similarity and interdependence, began the one form. Therefore, the state's activity in this regard was considered as a separate branch. Maintaining and safeguarding security, public order required systematic surveillance. It would probably prompted King Louis $\mathrm{XIV}$, in 1667, to entrust security, peace and public order to one central office in Paris - the Bureau of Trust and Security. Finally, the concept of police was clarified in the Prussian Landrecht of 1794 and the French Penal Code of 1795 and adopted in a similar manner by the legislation of other countries. Understanding this concept requires the activity of the internal administration to protect the security of peace and public order. It should be noted that in the nineteenth century, the objectives and tasks of police were strictly defined (Pokruszyński, Straszewski, Terlikowski, 1996, p. 11). At present, the term police means uniformed and armed formation serving the public and intended to protect the safety of people as well as to maintain public safety and order. 


\section{Philosophy}

In the tradition of social philosophy exposed by Thomas Hobbes, concerning artificial objects, security is a denial of mistrust. Because, the distrust embedded in individualism and natural - in his view - the human asylum is a threat to the common life. This tradition has left its mark on associating security more with the absence or absence of mistrust as a fundamental threat to social life and social life. This state as a lack of danger and certainty is both realistically and practically more accomplished by the custody of someone or something, their care and protection, and guardianship. The task of this custody, care and care, Hobbes entrusted to the state (Świniarski, 2011, p. 121). From the axiological holism point of view, the narrowing of security to the political dimension and monistic conception is not justified. This holism contributes to a broad understanding of security, which, in the philosophy advocated by philosophy, covers at least four basic dimensions. J. Swiniarski presents them as (Swiniarski, 2011, p. 134):

1. Demographic as procreation and education, focused on survival.

2. Economical as prosperity and prosperity, oriented towards continuity.

3. Political as a law and system, oriented towards development.

4. Cultural as freedom and responsibility, oriented towards improvement.

Thus, the philosophical view of security can be defined as making things so as to ensure continuity through procreation and education, survival by prosperity and prosperity, development by proper law (the rule of law), and the organization of social life (rather active participation in this life as citizens have already advocated Aristotle) and refining by respecting freedom and responsibility for oneself, others and nature. Internal security, in times of globalization and the dominance of liberal democracy in the axiological perspective, seems to rely mainly on the care, survival, development and improvement of the national community (Swiniarski, 2011, p. 134).

\section{Sociology}

It can be assumed that, on sociology issue, the security is an obligatory and sanctioned in a given community, a social system of individual behavior that allows them and other members of the community to survive without 
risking the impact that may affect her sense of fear of losing : life, health, property, nationality, statehood, religion, value system, economic level, and other phenomena related to broadly understood safety and without fear of becoming a source of fear in others (Moczuk, 2009, p. 70).

Assuming, that security can become a category of sociological analysis, the question can be asked how it should be understood in terms of the various sociological directions that can be defined to the nature of classical theories, namely, functional theory, conflict theory, exchange theory, inter actionist theory and phenomenological theory (Turner, 1985). This type of security allows you to map the area of research and introduce safety issues into sociology, especially since depending on a particular sociological theory, the security should be investigated in every other way. Sociology should not only answer research questions, but should also provide generalizations that, thanks to a wide range of questions, can help in the understanding of the nature of security. It must be pointed out that sociology as science is changing, and the sociological concepts and theories of the 20th century change, thereby changing sociological concepts and theories (Moczuk, 2013, p.95).

\section{PsycholOgY}

The subjective perspective is the context of psychological research. Therefore, also in the psychological perspective, the security is not a clear concept. It is captured in several aspects: need, value and sense (Klamut, 2012, p. 42).

The hierarchy of the needs of the human person in the most readable and unambiguous manner was presented by Abraham Maslow, The need for safety, in addition to physiological needs, is the foundation of the functioning of every human being, defining these values as inferior needs.

In theory, the security is understood as a formal category consisting of specific need or needs, the content of which is related to the provision of basic mental conditions (Klamut, 2012, p. 43). S. Siek points out that the need of security corresponds to self-preservation instinct, and its unsatisfactoriness is associated with feeling anxiety (Siek, 1986, p. 32). A. Bańka even points out that security is a basic human needs and plays a big role in evaluating the environment and taking action (Bańka, 2002, pp. 227-230, see Klamut, 2012). 
Figure 1.

Maslow's pyramid of needs

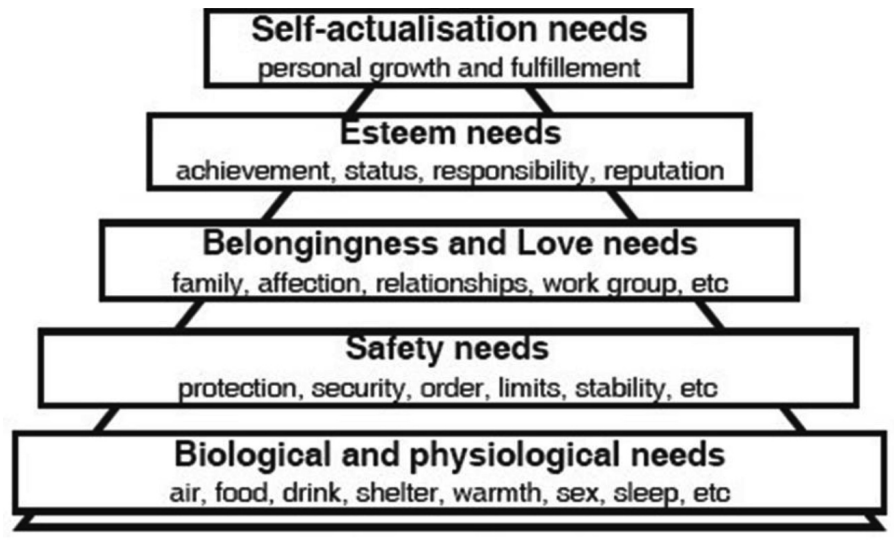

Source: https://carinatoledo.com/portfolio/ii-cimode-international-fashion-and-design congressarticle-presentation/ (see: 30.06.2017).

Values are cognitive constructions, they have the character of beliefs or concepts (Brzozowski, 2002, p. 28). At present, the most significant theory, developed by S. Schwartz, organizes values into certain categories of content. It brings them to: (1) directing one another, (2) stimulating, (3) hedonism, (4) attaining, (5) universalism (Schwartz, 1973, p. 1-2).

Based on empirical data, S. Schwartz sorted the categories outlined, pointing out the relationships between them. The most security-related are customization and tradition, which together constitute a meta-category defined as conservation. They are the most contradictory, and therefore difficult to reconcile with the values of the meta category opening on changes (it consists of directing and stimulating). Values are regarded as motivational factors, but are often indicated only by their aspect of meaning, „being valuable", without the psychology of understanding and their place in the motivational process. In this way, the safety is also indicated as a „factor that is important" in the direction of human activity (see Schwartz, 1973, Klamut, 2012, pp.44-45). Referring to the basic principles of motivation, one can point out that safety is more often experienced as a necessity. This context is more basic, hence more frequent and more powerful. First, a man strives to meet 
his own needs, later he or she discerns the importance of value and works by reading their meaning (Prężyna, 1996, p. 371). If safety needs are met and the individual realizes the values of safety, then the state of satisfaction, understood as a sense of security (Klamut, 2012, p. 46).

A concept that can be a criterion for assessing the level of psychological understanding of safety can be a sense of security. Feeling is the result of satisfying the need and realizing value (Klamut, 2002, p. 37). The sense of security is a state of experiencing calmness, certainty, feeling no danger, and the belief that sufficient resources are available for subjective actions. It is a state of experiencing satisfaction, the satisfaction resulting from having a specific (sufficient from the point of view of the individual) safety level (Klamut, 2012, p. 46). The psychological perspective, however, is a subjective perspective - it is less important than the external circumstances or actual actions, and the greater is how the person experiences and evaluates the situation (Nęcka, Orzechowski, Szymura, 2006, p. 27 et seq.). It may happen that in such a situation, where there is a problem of lack of adequacy of assessment and sense of security. Depending on the psychic factors and available information, the same external situation can be assessed differently. A person may experience a sense of security in a situation of high risk or a lack of sense of security in conditions of high stability and social peace (Klamut, 2012, p. 46).

One can point out that, from the three aspects of security, this sense of security is the most important context for understanding security in a psychological perspective. It is understood as the subjective state of experiencing peace, certainty, feeling no danger. It focuses on the subjective state of safety experience (Klamut, 2012, p. 48).

\section{Summary}

Today's world is not without its perceptible and real threats, which origins can be traced to political, economic, national, ethnic or religious antagonisms. Contradictions and diversity of interests generate multiple dangers: from armed conflicts and terrorist attacks to common and organized crime, hooligan excesses, infectious information systems or corruption. In addition to the dangers posed by the attitude and activity of man, the natural disasters are also important for safety. The process of globalization also means that 
international threats, quickly becomes a real danger, destabilizing national or local security (Misiuk, 2013, p. 9). The doctrinal definitions of the concept of public security and public policy clearly indicate that the state of public security and public order depends on the nature of its threats. Also, in the law, despite the absence of definition, threats are indicated (Pieprzny, 2007, p. 46). Therefore, when attempting to define the notion of security and public order in the field of legal sciences, based solely on legal acts, this should be done by indicating its designations. In others, it is much easier for scientific disciplines, as the doctrine in this area is much more established.

To sum up, the interdisciplinary nature of the title issue undoubtedly forces a multi-faceted perception of security and public policy. It should be stated that the introduction of the subject matter into the framework of only one of the scientific disciplines in a meaningful manner may diminish the guiding principle without giving full effect to the content of the security and public order concept.

\section{References:}

Antonowicz, M. Łukasik, K. (2011). Bezpieczeństwo publiczne. Warszawa: Wyższa Szkoła Zarządzania i prawa im. Heleny Chodkowskie.

Bańka, A. (2002). Społeczna psychologia środowiskowa. Warszawa: Wydawnictwo Naukowe „Scholar”. ISBN 8373690050.

Bolesta, S. (1972). Pozycja prawna MO w systemie organów PRL. Warszawa: Departament Szkolenia i Doskonalenia Zawodowego Ministerstwa Spraw Wewnętrznych.

Brzozowski, P. (2002). Uniwersalność struktury wartości: Koncepcja Shaloma H. Schwarza. Roczniki psychologiczne 5/2002. ISSN 1507-7888.

Dobkowski, J. (2008). Administracja bezpieczeństwa i porządku publicznego wobec integracji europejskiej (wybrane uwagi). w: E. Ura, K. Rajchel, M. Pomykała, S. Pieprzny (red.), Bezpieczeństwo wewnętrzne we współczesnym państwie. Rzeszów: Politechnika Rzeszowska im. Ignacego Łukasiewicza : Uniwersytet Rzeszowski. ISBN 9788392640592.

Filaber, J. (2009). Pojęcie bezpieczeństwa publicznego w prawie administracyjnym (wybrane uwagi). w: M. Sadowski, P. Szymaniec (red.), Prace prawnicze, administratywistyczne i historyczne, „Wrocławskie Studia Erazmiańskie. Zeszyty Studenckie", Wrocław. ISSN 1689-8974.

Glaser, S. (1933). Polskie prawo karne w zarysie. Kraków: Księg. Powszechna,. 
Klamut, R. (2002). Cel - czas - sens życia. Lublin: TNKUL. ISBN 8373060855.

Klamut, R. (2012). Bezpieczeństwo jako pojęcie psychologiczne. Zeszyty Naukowe Politechniki Rzeszowskiej, Ekonomia i Nauki Humanistyczne 2012/4, Rzeszów. ISSN 1234-3684.

Marek, A. (2007). Kodeks karny. Komentarz, Warszawa: Wolters Kluwer Polska Sp. z o.o. ISBN 9788375263251.

Maslow, A. (1943). A Theory of Human Motivation, „Psychological Review”, 50/1943. ISSN 033-295X.

Misiuk, A. (2011). Administracja porządku i bezpieczeństwa publicznego. Zadania prawno-ustrojowe. Warszawa: Wydawnictwa Akademickie i Profesjonalne. ISBN 9788360501887.

Misiuk, A. (2013). Instytucjonalny system bezpieczeństwa wewnętrznego. Warszawa: Difin.ISBN 9788376419916.

Moczuk, E. (2009). Socjologiczne aspekty bezpieczeństwa lokalnego. Rzeszów: Uniwersytet Rzeszowski. ISBN 9788373384378.

Moczuk, E. (2013). Bezpieczeństwo jako kategoria analizy socjologicznej. Ius et Administratio 3/2013. ISSN 1732-7318.

Nęcka, E. Orzechowski, J. Szymura, B. (2006). Psychologia poznawcza, Warszawa: Wydawnictwo Naukowe PWN : Academica Wydawnictwo SWPS. ISBN 9788301145866.

Pieprzny, S. (2007). Ochrona bezpieczeństwa i porządku publicznego w prawie administracyjnym. Rzeszów: Wydawnictwo Uniwersytetu Rzeszowskiego. ISBN 9788373383388.

Pieprzny, S. (2012). Administracja bezpieczeństwa i porządku publicznego. Rzeszów: Wydawnictwo Uniwersytetu Rzeszowskiego. ISBN 9788373387317.

Pikulski, S. (2000). Podstawowe zagadnienia bezpieczeństwa publicznego. w: W. Bednarek, S. Pikulski (red.), Prawne i administracyjne aspekty bezpieczeństwa osób i porządku publicznego w okresie transformacji ustrojowo-gospodarczej. Olsztyn: Wydaw. UW-M. ISBN 8372990433.

Pływaczewski, E. (1985). Przestępstwo czynnej napaści na funkcjonariusza publicznego. Toruń: UMK. ISBN 8323100160.

Pokruszyński, W. Straszewski, K. Terlikowski, T. (1996). System bezpieczeństwa publicznego Polski. Warszawa.

Pomykała, M. (2010). Bezpieczeństwo - w poszukiwaniu definicji. Zeszyty Naukowe Politechniki Rzeszowskiej, Zarządzanie i Marketing 2010/17, Rzeszów. ISSN 1234-3706. 
Pomykała, M. (2012). Bezpieczeństwo jako kategoria prawa, w: A. Letkiewicz, A. Misiuk (red.) Państwo - Administracja - Policja. Księga pamiątkowa dedykowana Profesorowi Kazimierzowi Rajchelowi, Szczytno: Wydział Wydawnictw i Poligrafii Wyższej Szkoły Policji. ISBN 9788374623216.

Popielski, K. (1996). Społeczno-religijne odniesienia poczucia sensu życia i psychoterapii. w: K. Popielski (red.), Człowiek - wartości - sens. Studia z psychologii egzystencji. Lublin: Redakcja Wydawnictw KUL. ISBN 8322805233.

Siek, S. (1986). Struktura osobowości. Warszawa.

Świniarski, J. (2011). Bezpieczeństwo wewnętrzne w ujęciu filozoficznym. w: L. Grochowski, A. Letkiewicz, A. Misiuk (red.), Nauka o bezpieczeństwie. Istota, przedmiot badań i kierunki rozwoju. Studia i materiały. Tom I, Szczytno: Wydawnictwo Wyższej Szkoły Policji. ISBN 9788374623056.

Turner, J. (1985). Struktura teorii socjologicznej, Warszawa: Wydawnictwo Naukowe PWN. ISBN 9788301140724.

Ura, E. (1974). Pojęcie ochrony bezpieczeństwa i porządku publicznego. Państwo i Prawo 1974(2). ISSN 0031-0980.

Ura, E. (1997). Prawo administracyjne. Część druga. Rzeszów: "Fosze”. ISBN $838628272 X$.

Ura, E. Pieprzny, S. Pado, T. (2007). Pojęcie bezpieczeństwa publicznego w prawie administracyjnym. w: J. Zimmermann (red.), Koncepcja systemu prawa administracyjnego. Zjazd Katedr Prawa Administracyjnego i Postępowania Administracyjnego, Zakopane 24-27 września 2006 r., Warszawa.

Wojtyczek, K. (1999) Granice ingerencji ustawodawczej w sferę praw człowieka w Konstytucji RP. Kraków: “Zakamycze”. ISBN 8388114093.

Zaborowski, J. (1977). Prawne środki zapewnienia bezpieczeństwa i porządku publicznego. Warszawa: Departament Szkolenia i Doskonalenia Zawodowego MSW.

\section{Legal acts}

Konstytucja Rzeczpospolitej Polskiej z dnia 2 kwietnia 1997 r. (Dz.U. Nr 78, poz. 483 ze zm.).

Ustawa z dnia 6 czerwca 1997 r. - Kodeks karny (Dz.U. z 2016 r., poz. 1137).

Ustawa z dnia 8 marca 1990 r. o samorządzie gminnym (Dz.U. z 2016 r., poz. 446).

Uchwała Centralnej Komisji do Spraw Stopni i Tytułów z dnia 28 stycznia 2011 r. zmieniającą uchwałę w sprawie określania dziedzin nauki i dziedzin sztuki oraz dyscyplin naukowych i artystycznych (M.P. z 2011 r., nr 14, poz. 149). 


\section{Internet source}

Bogdan, G. (2016). Komentarz do art. 163 Kodeksu karnego. LEX.

Schwartz, S.H. (1973). Basic Human Values: An Overview, Pozyskano (17.06.2017) $\mathrm{z}$ http://segrdid2.fmag.unict.it/Allegati/convegno\%207-8-10-05/Schwartzpaper.pdf). 